\title{
Psychogenomics: Opportunities for Understanding Addiction
}

\author{
Eric J. Nestler \\ Department of Psychiatry and Center for Basic Neuroscience, The University of Texas Southwestern Medical Center, \\ Dallas, Texas 75390-9070
}

The term psychogenomics is used here to describe the process of applying the powerful tools of genomics and proteomics to achieve a better understanding of the biological substrates of normal behavior and of diseases of the brain that manifest themselves as behavioral abnormalities. Applying psychogenomics to the study of drug addiction will lead to the identification of genes and their protein products that control the reward pathways of the brain and their adaptations to drugs of abuse, as well as variations in these genes that confer genetic risk for addiction and related disorders. The ultimate goal is to use this information to develop more effective treatments for these disorders as well as objective diagnostic tools, preventive measures, and eventually cures.
Drug addiction, like all other psychiatric disorders, is diagnosed today solely on the basis of the behavioral abnormalities that patients exhibit. For example, addiction can be defined as compulsive drug seeking and taking despite adverse consequences or as loss of control over drug use. However, there is no objective diagnostic information we can offer individuals concerning their risk for addiction in general, let alone addiction for a specific substance, nor can we offer patients informed advice concerning their risk for relapse. Moreover, current treatments for drug addiction are inadequate for most individuals.

The goal of this review is to outline ways in which recent advances in functional genomics and proteomics can be expected to dramatically improve psychiatric practice overall and the treatment of addictive disorders in particular. Two major areas of advances in this evolving field of "psychogenomics" are seen: (1) identification of genes that confer risk for an addiction and (2) identification of genes and proteins that contribute to the regulation of reward, motivation, and cognition under normal circumstances and to abnormalities in these behaviors that characterize an addicted state. There is now considerable optimism that these advances will lead one day to objective diagnostic tests, improved treatments, and eventually preventive measures and cures.

\section{Identification of addiction vulnerability genes}

Epidemiological studies have indicated that drug addiction is a highly heritable disorder. Approximately 40-60\% of the risk for alcohol, cocaine, or opiate addiction appears to be genetic (Nestler, 2000). Data are not yet available for nicotine or other substances, although anecdotal information suggests similar degrees of heritability. In addition, we do not yet know the genetic risk for other forms of compulsive behavior, such as to food, sex, and gambling. The evolving knowledge that these disorders involve some of the same neural mechanisms as drug addiction would suggest a significant genetic risk as well. Despite this genetic basis, however, efforts to identify specific genes involved

\footnotetext{
This work was supported by grants from the National Institute on Drug Abuse.

Correspondence should be addressed to Eric J. Nestler, Department of Psychiatry and Center for Basic Neuroscience, The University of Texas Southwestern Medical Center, 5323 Harry Hines Boulevard, Dallas, TX 75390-9070. E-mail: eric.nestler@utsouthwestern.edu.

Copyright (C) 2001 Society for Neuroscience $0270-6474 / 01 / 218324-04 \$ 15.00 / 0$
}

in drug addiction have not to date been successful. The difficulty in finding such genes is comparable with the difficulty in finding genes for other common conditions (e.g., hypertension, congestive heart failure, and asthma) (Burmeister, 1999). One possibility is that these diseases are caused by a relatively large number of genes, such that it is extremely difficult to identify the individual genes involved, each of which is only responsible for a small percentage of the overall risk. Another possibility is that the tools for fine genome-wide scans in large numbers of individuals have only recently become available, such that the pessimism is premature.

Two major approaches have been used to identify the genetic causes of addiction. One is a candidate gene approach, in which genes and proteins implicated in the pathophysiology or in animal models of addiction are considered as human risk factors. The validity of the candidate gene approach is supported by situations in which obvious candidate genes have been related to human disease. An example is Alzheimer's disease, which is characterized by the accumulation of $\beta$-amyloid in the brain, and where rare familial variants of the disorder are caused by mutations in amyloid precursor protein (APP), from which $\beta$-amyloid is derived (Selkoe, 2001). Another example is frontotemporal dementia, which is characterized by hyperphosphorylation of the microtubule-associated protein $\tau$; this disorder is caused in some families by mutations in the $\tau$ gene (Pickering-Brown et al., 2000). However, use of the candidate gene approach in the addiction field is hampered by our still limited knowledge of the pathophysiology of these disorders in humans. Consequently, investigators have focused on genes implicated in animal models, which are only now being revealed and have not yet been evaluated in human populations (see below).

The other approach is open-ended and involves genome-wide scans of affected and unaffected individuals. The necessity of this approach is based on the experience that the genetic abnormalities underlying most of those neuropsychiatric disorders for which such abnormalities have been found occur in genes that would never have been considered candidates. Examples include a gene encoding a DNA methylation-regulating protein in Rett's syndrome (an autism-like disorder) (Shahbazian and Zoghbi, 2001) and previously unknown genes in Huntington's disease (Gutekunst 
et al., 2000), familial forms of Parkinson's disease (de Silva et al., 2000), and neurofibromatosis (Parada, 2000), to name a few. The technology to complete genome-wide scans has improved dramatically in recent years, and there is currently a great deal of anticipation that this approach will begin to identify genetic factors related to addiction over the next 5-10 years.

Another open-ended approach involves searching for abnormal levels of mRNAs or proteins in brain tissue obtained from addicted individuals at autopsy. DNA microarrays and other methods of differential gene expression have greatly augmented the ability of the field to find such abnormalities, and some promising early studies have been published recently for other psychiatric syndromes, such as schizophrenia (Mirnics et al., 2000). One limitation of this approach is that in most cases the brains are obtained long after the initial manifestation of the disease, and this time delay may obscure primary pathophysiological changes. Some of the observed changes might even represent normal compensations to the primary abnormalities and not components of them. Another limitation is that the exact locations of the primary pathology in human addiction are not known with certainty, although animal models have indicated several brain regions of likely importance (e.g., the ventral striatum, prefrontal cortex, and midbrain dopamine nuclei) (Koob et al., 1998; Wise, 1998).

Knowledge of genes that confer risk for addiction could one day be used to select the optimal treatment program for an individual addict. For example, in the depression field, some antidepressants are serotonin-reuptake inhibitors, whereas others inhibit norepinephrine reuptake. There is a major effort today to identify genetic factors that can be used to predict whether a person with depression would respond better to one or the other. Such pharmacogenomic studies are in their early stages, and would appear premature for addiction, because treatments for drug addiction, and our knowledge of the underlying genetic factors, are still limited.

Once addiction vulnerability genes or genes that predict pharmacological responses are discovered, the next step will be to place these genes in mice to enable studies of the underlying molecular and neural mechanisms that link the genes to abnormal behavior. For example, before the identification of genes that cause Alzheimer's disease, Huntington's disease, or Rett's syndrome, animal models were extremely limited. Now that the genetic abnormalities underlying these disorders have been revealed, it has been possible to generate mice that offer much better models for studying disease pathophysiology and possible therapeutic interventions (Chen et al., 2001; Guidetti et al., 2001; Selkoe, 2001). Such improved animal models of addiction would offer a powerful means of identifying nongenetic factors that also contribute to these disorders. In the absence of knowing the specific genes involved, the field has had a difficult time defining specific environmental risk factors for addiction, beyond rather vague generalities such as stress, poverty, crime, and dysfunctional families.

\section{Genetic dissection of complex behavior}

Considerable progress has been made in identifying genes that regulate complex behavior relevant to addiction in animal models. Such discoveries have aided efforts to define neural circuits in the brain that control these behaviors. They also have the potential of revealing candidate genes that could be studied in human disorders. As with human genetic studies, genomic and proteomic efforts in animals can be divided between candidate and openended approaches.

Candidate approaches have offered major insights into the influence of specific genes and proteins in the regulation of reward, motivation, and cognitive function, to name a few behaviors. Such advances are much too numerous to elaborate here. The role of specific neurotransmitter receptors (e.g., for dopamine, glutamate, and serotonin), intracellular signaling proteins (e.g., protein kinases, arrestins, and dopamine and cAMPregulated phosphoprotein of $32 \mathrm{kDa}$ ), and transcription factors (e.g., cAMP response element-binding protein and $\Delta \mathrm{FosB}$ ) in these various behaviors are just some examples of the important strides made in the past decade (Carlezon et al., 1998; Fienberg et al., 1998; Stark et al., 1998; Kelz et al., 1999; Mayford and Kandel, 1999; Bohn et al., 2000; Nestler, 2000).

The ability to relate a particular gene to a complex behavior requires the ability to manipulate genes within an animal. Firstgeneration transgenic and knock-out mice continue to represent the mainstay of efforts in this field. However, there also is increasing recognition of the need to manipulate a gene with much greater spatial and temporal control (i.e., to induce the mutation in a specific brain region of an adult animal). This need is attributable to the fact that interpretation of transgenic and knock-out mice can be complicated by developmental effects and the ubiquitous nature of the mutation. Some of the tools that have been used to obtain greater spatial and temporal control include antisense oligonucleotides, viral-mediated gene transfer, and the creation of inducible, cell-targeted mutations in mice. Although improvements are needed in these approaches, their unique power to genetically dissect behavior has been demonstrated in recent years (Carlezon et al., 1998; Kelz et al., 1999; Mayford and Kandel, 1999; Pooga et al., 2001).

Several open-ended approaches also have been used. DNA microarrays are just now beginning to be used to identify druginduced changes in the brain, and some early reports have appeared (Lewohl et al., 2000; Ang et al., 2001; Bibb et al., 2001; Freeman et al., 2001). One limitation of current microarray technology is its sensitivity (i.e., its ability to detect low-abundance messages). This has directed efforts to alternate methodologies of differential gene expression, which may offer greater sensitivity (Gautvik et al., 1996). Likewise, the need for proteomic approaches cannot be overstated. Most current high-throughput efforts have for technical reasons focused on analysis of mRNAs. Yet a major need in the field is to develop methods of comparable throughput to study proteins, including total amounts of proteins as well as their modification by phosphorylation, glycosylation, etc. (Zhang et al., 2001). One example of the need for proteomics is provided by consideration of the transcription factor $\Delta F$ FosB (Nestler et al., 2001). $\Delta$ FosB is induced in striatal regions of brain uniquely after chronic exposure to drugs of abuse, and persists in the brain for weeks to months after drug exposure ceases. Increasing evidence indicates that $\Delta$ FosB is an important molecular substrate for addiction. However, the induction of $\Delta$ FosB resides in the protein, which is highly stable, and not in its mRNA, which is highly unstable. Thus, a genomics-only approach would never have succeeded in identifying $\Delta$ FosB as a long-lasting adaptation associated with addiction.

Large-scale mutagenesis studies, in which mutations are randomly induced by chemical mutagens and resulting behavioral abnormalities are explored in broad-based behavioral screens, are now getting underway. A challenge in the addiction field is that behaviors that most closely model human addiction (see below) 
are not amenable to the high throughput needed in mutagenesis studies. As a result, more rapid assays, such as stimulant-induced locomotor activity, are being used. The potential of this strategy is indicated by recent studies, which have identified novel genes involved in circadian rhythms (Lowrey and Takahashi, 2000; Tarantino and Bucan, 2000). Quantitative trait locus (QTL) analysis is another open-ended approach to find genes that contribute to behavioral differences between inbred mice or rats, including differential responses to drugs of abuse (Crabbe et al., 1999). Numerous QTLs have been found, but it has been exceedingly difficult to narrow these large chromosomal regions to specific genes. Whether improved genomic tools now available will improve the situation is unclear. Still, the potential of animal genetics is indicated by the identification of the orexin receptor as the site of mutation in a hereditary narcolepsy-like syndrome in dogs (Hungs and Mignot, 2001). This, together with related findings in mice (see below), has provided a compelling scenario of the pathophysiology of narcolepsy in humans.

The ability to relate genes to complex behavior requires not only the means of manipulating and detecting genes and their products but also precise tests of complex behavior in laboratory animals as well as accurate animal models of human disease. There are indeed numerous tests of many types of behavior in rodents that have been used widely in the field. Some examples include measures of cognitive function, fear, and reward. In addition, whereas animal models of human psychiatric disease have been problematic, the situation is better for addiction, because it is possible to measure in animals not only acute drug reward but also phenomena more referable to human addictions, such as drug seeking and craving (Koob et al., 1998; Self and Nestler, 1998; Wise, 1998). Such animal models should be improved further when genes that contribute to addiction risk in humans can be put into rodents to reproduce human vulnerability states.

\section{Clinical applications of psychogenomics}

As genomic and proteomic efforts succeed in identifying genes and proteins involved in normal behavior and in addiction, several tangible benefits will result. The most obvious is the identification of novel targets for psychotherapeutic medications. All but a few currently used psychiatric medications act on neurotransmitter receptors or transporter proteins. Yet these proteins represent a miniscule fraction of all neuronal proteins, and it is likely that among this remaining array of proteins are viable drug targets, including targets for truly effective anti-addiction medications. The challenge is to find them.

Several examples illustrate how genomics and proteomics provide a rationale guide. In the Alzheimer's field, knowledge of the abnormal processing of APP into $\beta$-amyloid suggested the existence of a $\beta$-secretase that catalyzes this processing. Such an enzyme has now been identified through genomic efforts and inhibitors are being developed as possible treatment agents for Alzheimer's disease (Yan et al., 1999). Another example is provided by the obesity field. Identification of the leptin and leptin receptor genes, based on their abnormalities in two spontaneous lines of mutant mice, the $\mathrm{Ob}$ (obese) and $\mathrm{Db}$ (diabetic) mice, has led to explosive knowledge of the regulation of eating behavior and to the identification of numerous peptides and their receptors as potential targets for new medications (Friedman and Halaas, 1998). Regulators of G-protein signaling (RGS) proteins act by sharpening the responses of G-protein-coupled receptors and perhaps by serving as scaffolding proteins (Berman and Gilman,
1998). They were discovered initially through genomic efforts in yeast and worms. There is considerable diversity among RGS proteins, with 25 products now identified in mammals. Many are enriched in the brain, where several show striking region-specific patterns of expression (Gold et al., 1997). The pharmaceutical industry is now evaluating whether drugs aimed at RGS subtypes might be useful in the treatment of psychiatric disorders including addiction. The serendipitous discovery of a narcolepsy-like syndrome in orexin knock-out mice (Chemelli et al., 1999) and the related findings in dogs stated previously led to the view that human narcolepsy is caused by a loss of orexin-containing neurons in the lateral hypothalamus. The development of orexin agonists to treat narcolepsy is now a tangible goal. Similarly, as we define the detailed etiology and pathophysiology of addiction, it should be possible to develop medications that intervene in the addiction process. Such medications will not replace psychosocial interventions that are now offered to addicts but will likely make such rehabilitation efforts far more useful. Indeed, psychosocial interventions may be doomed to failure in many patients until medications are developed to effectively counter the powerful biological forces that drive a state of addiction.

Advances in our understanding of the genetics and neurobiology of drug addiction will have dramatic implications for diagnosis and prevention as well. It is not farfetched to envision the day when a patient with a behavioral abnormality, such as an addiction, undergoes a battery of tests, including genetic tests and perhaps brain-imaging scans, to define a disease entity and to choose the most effective course of treatment. It might be possible to identify and educate individuals who are particularly vulnerable to a specific drug (e.g., those for whom even brief exposures to a drug of abuse pose a substantial risk for addiction).

\section{The future of psychogenomics}

Psychogenomics will probably be the last frontier of the functional genomics revolution. This is because of the complexity of the brain and the obstacles inherent in diagnosing and treating brain diseases, such as the enclosure of the brain within the skull and the lack of access to tissue from living patients. Within psychogenomics, however, the addiction field may lead the way, based on the relative ease of relating molecular events to meaningful animal models of the human disorders. The fields of genomics and proteomics provide tools of unprecedented power to identify genes and proteins that control complex behavior under normal and pathological conditions. Eventually, these discoveries can be exploited for clinical applications as diverse as improved treatments, diagnostic tests, and ultimately disease prevention and cure.

\section{REFERENCES}

Ang E, Chen JS, Zagouras P, Magna H, Holland J, Schaeffer E, Nestler EJ (2001) Induction of $\mathrm{NF} \kappa \mathrm{B}$ in nucleus accumbens by chronic cocaine administration. J Neurochem 79:221-224.

Berman DM, Gilman AG (1998) Mammalian RGS proteins: barbarians at the gate. J Biol Chem 273:1269-1272.

Bibb JA, Chen J, Taylor JR, Svenningsson P, Nishi A, Snyder GL, Yan Z, Sagawa ZK, Ouimet CC, Nairn AC, Nestler EJ, Greengard P (2001) Effects of chronic exposure to cocaine are regulated by the neuronal protein Cdk5. Nature 410:376-380.

Bohn LM, Gainetdinov RR, Lin FT, Lefkowitz RJ, Caron MG (2000) $\mu$-opioid receptor desensitization by $\beta$-arrestin- 2 determines morphine tolerance but not dependence. Nature 408:720-723.

Burmeister M (1999) Basic concepts in the study of diseases with complex genetics. Biol Psychiatry 45:522-532.

Carlezon Jr WA, Thome J, Olson VG, Lane-Ladd SB, Brodkin ES, Hiroi N, Duman RS, Neve RL, Nestler EJ (1998) Regulation of cocaine reward by CREB. Science 282:2272-2275.

Chemelli RM, Willie JT, Sinton CM, Elmquist JK, Scammell T, Lee C, 
Richardson JA, Williams SC, Xiong Y, Kisanuki Y, Fitch TE, Nakazato M, Hammer RE, Saper CB, Yanagisawa M (1999) Narcolepsy in orexin knockout mice: molecular genetics of sleep regulation. Cell 98:437-451.

Chen RZ, Akbarian S, Tudor M, Jaenisch R (2001) Deficiency of methyl-CpG binding protein-2 in CNS neurons results in a Rett-like phenotype in mice. Nat Genet 27:327-331.

Crabbe JC, Phillips TJ, Buck KJ, Cunningham CL, Belknap JK (1999) Identifying genes for alcohol and drug sensitivity: recent progress and future directions. Trends Neurosci 22:173-179.

de Silva HR, Khan NL, Wood NW (2000) The genetics of Parkinson's disease. Curr Opin Genet Dev 10:292-298.

Fienberg AA, Hiroi N, Mermelstein PG, Song W, Snyder GL, Nishi A, Cheramy A, O'Callaghan JP, Miller DB, Cole DG, Corbett R, Haile CN, Cooper DC, Onn SP, Grace AA, Ouimet CC, White FJ, Hyman SE, Surmeier DJ, Girault J, Nestler EJ, Greengard P (1998) DARPP32: regulator of the efficacy of dopaminergic neurotransmission. Science 281:838-842.

Freeman WM, Nader MA, Nader SH, Robertson DJ, Gioia L, Mitchell SM, Daunais JB, Porrino LJ, Friedman DP, Vrana KE (2001) Chronic cocaine-mediated changes in non-human primate nucleus accumbens gene expression. J Neurochem 77:542-549.

Friedman JM, Halaas JL (1998) Leptin and the regulation of body weight in mammals. Nature 395:763-770.

Gautvik KM, de Lecea L, Gautvik VT, Danielson PE, Tranque P, Dopazo A, Bloom FE, Sutcliffe JG (1996) Overview of the most prevalent hypothalamus-specific mRNAs, as identified by directional tag PCR subtraction. Proc Natl Acad Sci USA 93:8733-8738.

Gold SJ, Ni YG, Dohlman H, Nestler EJ (1997) Regulators of G-protein signaling: region-specific expression of nine subtypes in rat brain. J Neurosci 17:8024-8037.

Guidetti P, Charles V, Chen EY, Reddy PH, Kordower JH, Whetsell Jr WO, Schwarcz R, Tagle DA (2001) Early degenerative changes in transgenic mice expressing mutant huntingtin involve dendritic abnormalities but no impairment of mitochondrial energy production. Exp Neurol 169:340-350.

Gutekunst CA, Norflus F, Hersch SM (2000) Recent advances in Huntington's disease. Curr Opin Neurol 13:445-450.

Hungs M, Mignot E (2001) Hypocretin/orexin, sleep, and narcolepsy. BioEssays 23:397-408.

Kelz MB, Chen J, Carlezon Jr WA, Whisler K, Gilden L, Beckmann AM, Steffen C, Zhang YJ, Marotti L, Self DW, Tkatch T, Baranauskas G, Surmeier DJ, Neve RL, Duman RS, Picciotto MR, Nestler EJ (1999) Expression of the transcription factor $\Delta$ FosB in the brain controls sensitivity to cocaine. Nature 401:272-276.
Koob GF, Sanna PP, Bloom FE (1998) Neuroscience of addiction. Neuron 21:467-476.

Lewohl JM, Wang L, Miles MF, Zhang L, Dodd PR, Harris RA (2000) Gene expression in human alcoholism: microarray analysis of frontal cortex. Alcohol Clin Exp Res 24:1873-1882.

Lowrey PL, Takahashi JS (2000) Genetics of the mammalian circadian system: photic entrainment, circadian pacemaker mechanisms, and posttranslational regulation. Annu Rev Genet 34:533-562.

Mayford M, Kandel ER (1999) Genetic approaches to memory storage. Trends Genet 15:463-470.

Mirnics K, Middleton FA, Marquez A, Lewis DA, Levitt P (2000) Molecular characterization of schizophrenia viewed by microarray analysis of gene expression in prefrontal cortex. Neuron 28:53-67.

Nestler EJ (2000) Genes and addiction. Nat Genet 26:277-281.

Nestler EJ, Barrot M, Self SW (2001) $\Delta$ FosB: a molecular switch for addiction. Proc Natl Acad Sci USA 98:11042-11046.

Parada LF (2000) Neurofibromatosis type 1. Biochim Biophys Acta 1471:M13-M19.

Pickering-Brown S, Baker M, Yen SH, Liu WK, Hasegawa M, Cairns N, Lantos PL, Rossor M, Iwatsubo T, Davies Y, Allsop D, Furlong R, Owen F, Hardy J, Mann D, Hutton M (2000) Pick's disease is associated with mutations in the $\tau$ gene. Ann Neurol 48:859-867.

Pooga M, Land T, Bartfai T, Langel U (2001) PNA oligomers as tools for specific modulation of gene expression. Biomol Eng 17:183-192.

Self DW, Nestler EJ (1998) Relapse to drug seeking: neural and molecular mechanisms. Drug Alcohol Depend 51:49-60.

Selkoe DJ (2001) Alzheimer's disease: genes, proteins, and therapy. Physiol Rev 81:741-766.

Shahbazian MD, Zoghbi HY (2001) Molecular genetics of Rett syndrome and clinical spectrum of MECP2 mutations. Curr Opin Neurol 14:171-176.

Stark KL, Oosting RS, Hen R (1998) Novel strategies to probe the functions of serotonin receptors. Biol Psychiatry 44:163-168.

Tarantino LM, Bucan M (2000) Dissection of behavior and psychiatric disorders using the mouse as a model. Hum Mol Genet 9:953-965.

Wise RA (1998) Drug-activation of brain reward pathways. Drug Alcohol Depend 51:13-22.

Yan R, Bienkowski MJ, Shuck ME, Miao H, Tory MC, Pauley AM, Brashier JR, Stratman NC, Mathews WR, Buhl AE, Carter DB, Tomasselli AG, Parodi LA, Heinrikson RL, Gurney ME (1999) Membrane-anchored aspartyl protease with Alzheimer's disease $\beta$-secretase activity. Nature 402:533-537.

Zhang HT, Kacharmina JE, Miyashiro K, Greene MI, Eberwine J (2001) Protein quantification from complex protein mixtures using a proteomics methodology with single-cell resolution. Proc Natl Acad Sci USA 98:5497-5502. 